\title{
BIOLOGICAL CHANGES OF GREEN PEA (PISUM SATIVUM L.) BY SELENIUM ENRICHMENT
}

\author{
Farzaneh Garousi, ${ }^{1 *}$ Béla Kovács, ${ }^{1}$ \\ Éva Domokos-SzabolcsY² and SzILVIa Veres ${ }^{2}$
}

\begin{abstract}
${ }^{1}$ Faculty of Agricultural and Food Sciences and Environmental Management, Institute of Food Science, University of Debrecen, H-4032 Debrecen, Böszörményi út 138. Hungary

${ }^{2}$ Faculty of Agricultural and Food Sciences and Environmental Management, Institute of Crop Sciences, University of Debrecen, Department of Agricultural Botany, Crop Physiology and Biotechnology, H-4032 Debrecen, Böszörményi út 138. Hungary
\end{abstract}

(Received: June 23, 2016; accepted: September 15, 2016)

\begin{abstract}
Supplement of common fertilizers with selenium (Se) for crop production will be an effective way to produce selenium-rich food and feed. The value of green pea seeds and forages as alternative protein source can be improved by using agronomic biofortification. Therefore, biological changes of green pea (Pisum sativum L.) and influences of inorganic forms of Se (sodium selenite and sodium selenate) at different concentrations on the accumulation of magnesium $(\mathrm{Mg})$ and phosphorus $(\mathrm{P})$ were investigated in greenhouse experiment. $3 \mathrm{mg} \mathrm{kg}^{-1}$ of selenite had positive effects to enhance photosynthetic attributes and decrease lipid peroxidation significantly. At the same time, Se accumulation increased in all parts of plant by increasing Se supply. Moreover, $\mathrm{Mg}$ and $\mathrm{P}$ accumulations were significantly increased at $3 \mathrm{mg} \mathrm{kg}{ }^{-1}$ selenite and $1 \mathrm{mg} \mathrm{kg}^{-1}$ selenate treatments, respectively. By contrast higher selenite concentrations $(\geq 30$ $\mathrm{mg} \mathrm{kg}-1$ ) exerted toxic effects on plants. Relative chlorophyll content, actual photochemical efficiency of PSII $\left(\Phi_{\mathrm{PSII}}\right)$ and $\mathrm{Mg}$ accumulation showed significant decrease while membrane lipid peroxidation increased. Thus, the present findings prove Se biofortification has positive effects on biological traits of green pea to provide it as a proper functional product.
\end{abstract}

Keywords: Biological changes - sodium selenit - sodium selenate - biofortification - green pea

\section{INTRODUCTION}

Deficiencies in mineral micronutrients, including iron (Fe), zinc $(\mathrm{Zn})$, selenium (Se), and iodine (I), are affecting more than $50 \%$ of the world population [50]. Other minerals, such as calcium $(\mathrm{Ca})$, magnesium $(\mathrm{Mg})$, phosphorus $(\mathrm{P})$, and copper $(\mathrm{Cu})$ can also be deficient in the diets of some populations [42].

Biofortification, with aims of increasing micronutrient amounts in the edible parts of plants via breeding or the applying of biotechnology, is considered to be a costeffective way to diminish micronutrient malnutrition in the rural populations in developing countries where the problem is most common [23, 27]. Biofortification may also include other approaches, such as the use of micronutrient fertilizers (agronomic biofortification) or enhancement of micronutrient bioavailability by manipulating the levels of pronutrient or antinutrient components in foods [10].

*Corresponding author; e-mail address: farzaneh@agr.unideb.hu 
Se is an essential element absorbed mostly from dietary sources in animals and humans. It is important in the prevention of several cancers, protection against viral infections oxidative stress, inflammation and suppression of HIV progression to AIDS [7]. Crop plants play an important role as a source of Se. Agronomic biofortification with Se enriched fertilizer has been widely tested based on field, pot and hydroponic experiments $[3,5,9,20,40]$. Currently, possible interactions and competition between Se and other major and trace elements are key scientific issues, too [13, $18,45]$. In plants, Se influences enzymatic antioxidant activities [8, 14], in which essential cations acted as enzyme co-factors. These cations play crucial roles in plant metabolism. $\mathrm{Mg}$ is involved in the maintenance of membrane stability and plant tissues integrity. $\mathrm{Mg}$ is also essential for the enzymatic activity of glutathione synthetase and ATPases [22]. In addition, phosphorus $(\mathrm{P})$ is an essential macronutrient for plant growth and development $[38,44]$, too. As $\mathrm{P}$ is often deficient in soil or exists in unavailable forms that cannot be directly utilized by plants $[1,32]$, crops require a large amount of $\mathrm{P}$ fertilizer to maintain normal growth in more than $30 \%$ of the world's arable land [39]. The application of $\mathrm{P}$ fertilizer improves crop production, but at the expense of causing severe environmental pollution and depletion of non-renewable $\mathrm{P}$ rocks $[38,39]$.

Plant species belonging to Fabaceae family are the second most important crops after cereals. Legumes are known as primary plant protein source. Pisum sativum, the common pea plant is one of the most important legumes. Pea is valued protein source primarily for the nutritional quality of its seeds for animal feed and human consumption while its pods and shoots can be used, as forage, too. Both pea seeds and forages are rich in protein including lysine and other essential amino acids [2]. Se can easily enter into amino acids instead of sulphur hence an elevated protein content of plants can contribute to the higher accumulation of Se [29]. This fact gives green pea the potential to be used in Se biofortification programs [36].

The objective of this study was to investigate the biological changes of green pea by sodium selenite and sodium selenate enrichment at different concentrations and also to evaluate the effects of them on the uptake and accumulation of macronutrients ( $\mathrm{Mg}$ and $\mathrm{P})$ in different plant tissues.

\section{MATERIALS AND METHODS}

The greenhouse pot experiments were performed with calcareous chernozem soil obtained from the Látókép Experimental Station of Debrecen University (N: 4733', E: $21^{\circ} 27^{\prime}, 113-118 \mathrm{~m}$ above of sea level). The parameters of this soil (Table 1) were essentially the same as previously described by Nagy et al. [26].

Eleven $\mathrm{kg}$ soil was weighed into Mitscherlich type pots $\left(50 \times 50 \mathrm{~cm}^{2}\right)$. A $100 \mathrm{~mL}$ additional NPK fertilization (contain $1.43 \mathrm{~g}$ nitrogen as $\mathrm{KNO}_{3}, 0.2291 \mathrm{~g} \mathrm{P}_{2} \mathrm{O}_{5}$ as $\mathrm{KH}_{2} \mathrm{PO}_{4}$ and $0.1487 \mathrm{~g} \mathrm{~K}_{2} \mathrm{O}$ as $\mathrm{K}_{2} \mathrm{SO}_{4}$ per pot) and $100 \mathrm{~mL} \mathrm{Se}$ (as two forms of sodium selenite $\left(\mathrm{Na}_{2} \mathrm{SeO}_{3}\right.$; active form: $\left.\mathrm{Se}^{\mathrm{IV}}\right)$ and sodium selenate $\left(\mathrm{Na}_{2} \mathrm{SeO}_{4}\right.$; active form: $\mathrm{Se}^{\mathrm{VI}}$ ) in five and four different concentrations, respectively, as follows: 0 (con- 
Table 1

Characteristics of the experimental soil

\begin{tabular}{|c|c|}
\hline Depth & $0-0.3 \mathrm{~m}$ \\
\hline $\mathrm{pH}(\mathrm{KCl})$ & 5.71 \\
\hline $\mathrm{pH}\left(\mathrm{H}_{2} \mathrm{O}\right)$ & 6.58 \\
\hline Soil texture category & loamy clay \\
\hline Total water-soluble salt & $0.015 \%$ \\
\hline $\mathrm{CaCO}_{3}$ & $0.202 \%$ \\
\hline Humus (organic matter) & $3.54 \%$ \\
\hline $\mathrm{KCl}$-soluble $\mathrm{NO}_{3}-\mathrm{N}+\mathrm{NO}_{2}-\mathrm{N}$ & $8.04 \mathrm{mg} \mathrm{kg}^{-1}$ \\
\hline AL-soluble $\mathrm{P}_{2} \mathrm{O}_{5}$ & $199 \mathrm{mg} \mathrm{kg}^{-1}$ \\
\hline AL-soluble $\mathrm{K}_{2} \mathrm{O}$ & $451 \mathrm{mg} \mathrm{kg}^{-1}$ \\
\hline AL-soluble $\mathrm{Na}$ & $332 \mathrm{mg} \mathrm{kg}^{-1}$ \\
\hline \multicolumn{2}{|c|}{ AL: $0.1 \mathrm{~mol} \mathrm{dm}^{-3}$ ammonium-lactate and $0.1 \mathrm{~mol} \mathrm{dm}^{-3}$ acetic-acid } \\
\hline KCl-soluble $\mathrm{Mg}$ & $176 \mathrm{mg} \mathrm{kg}^{-1}$ \\
\hline $\mathrm{KCl}$-soluble $\mathrm{SO}_{4}{ }^{2-}-\mathrm{S}$ & $6.04 \mathrm{mg} \mathrm{kg}^{-1}$ \\
\hline KCl-EDTA-soluble $\mathrm{Cu}$ & $5.79 \mathrm{mg} \mathrm{kg}^{-1}$ \\
\hline KCl-EDTA-soluble Zn & $7.9 \mathrm{mg} \mathrm{kg}^{-1}$ \\
\hline KCl-EDTA-soluble Mn & $262 \mathrm{mg} \mathrm{kg}^{-1}$ \\
\hline
\end{tabular}

trol), 1, 3, 10, 30 and $90 \mathrm{mg} \mathrm{kg}^{-1}$ and 0 (control), 1, 3, 10 and $30 \mathrm{mg} \mathrm{kg}^{-1}$, prepared with distilled water) were mixed and manually sprayed and supplemented to the soil as an aqueous solution - as evenly as possible - using dispenser bottles of $0.5 \mathrm{~L}$ (nominal volume). Green peas (Pisum sativum L.) were sown in separate experiments with three replications and the bi-factorial trials were arranged in a randomized complete block design. Pots were weighed daily and water loss was supplemented with ion exchanged water. At the third principal stage of growth; Stem elongation (the third true leaf has unfolded at the third node), immature plants were removed so that eight intact and mature plants were remained in every pot. Growing period lasted 50 days in May and June and the plants were harvested at the end of the seventh principal stage of growth; Development of fruit [Pods have reached typical size (green ripe)-peas fully formed].

Three $\mathrm{mg} \mathrm{kg}^{-1} \mathrm{Se}^{\mathrm{VI}}$ treatments stayed at flowering stage (sixth principal stage of growth) and did not grow more; 10 and $30 \mathrm{mg} \mathrm{kg}^{-1} \mathrm{Se}^{\mathrm{VI}}$ treatments did not even grow and stayed at the end of 0 principal stage of growth; Germination (Emergence: shoot breaks through soil surface). 


\section{Relative chlorophyll content (SPAD value)}

SPAD values as a relative chlorophyll content in the leaf were measured under natural conditions by using the SPAD chlorophyll meter (SPAD-502; Konica Minolta Sensing, Inc., Japan). The last fully developed leaves were measured at the end of growing period in 5 repetitions per pot.

\section{Chlorophyll fluorescence parameters}

Based on fluorescence induction kinetics, fluorescence parameters and ratios have been established to assess photochemical activity of plants. The parameters of in vivo chlorophyll fluorescence were detected with a PAM 2100 (Heinz Walz GmbH, Germany) modulated light fluorometer as described [33]. Samples were dark-adapted for 20 minutes. After dark adaptation, the initial fluorescence $\left(\mathrm{F}_{0}\right)$ was excited by weak light $\left(0.1 \mu \mathrm{mol} \mathrm{m} \mathrm{m}^{-2} \mathrm{~s}^{-1}\right)$ and the maximal fluorescence $\left(\mathrm{F}_{\mathrm{m}}\right)$ was induced by white saturating flash light $\left(8000 \mu \mathrm{mol} \mathrm{m}^{-2} \mathrm{~s}^{-1}\right)$. The actual photochemical efficiency of PSII as yield $\left(\Delta \mathrm{F} / \mathrm{F}_{\mathrm{m}},=\left(\mathrm{F}_{\mathrm{m}},-\mathrm{F}_{\mathrm{t}}\right) / \mathrm{F}_{\mathrm{m}},\right)$ was measured on the last fully developed leaves - at the end of growing period - on light-acclimated conditions under natural light between 11:00-12:00 $\mathrm{h}$. The photosynthetically active radiation was around $1200 \mu \mathrm{mol} \mathrm{m} \mathrm{m}^{-2} \mathrm{~s}^{-1}$ and the temperature was around $30{ }^{\circ} \mathrm{C}$.

\section{Malondialdehyde content}

Lipid peroxidation (LPO) was determined - at the end of growing period - from leaf blade by the method of Zhang and Huang [49], by measuring the amount of malondialdehyde (MDA). The leaf tissues $(\sim 100 \mathrm{mg})$ were homogenized in $1 \mathrm{~mL} 0.1 \%$ $(\mathrm{w} / \mathrm{v})$ trichloroacetic acid (TCA) solution using cold mortar and pestle. The homogenates were centrifuged at $10,000 \times \mathrm{g}$ for $10 \mathrm{~min}$. And then $4 \mathrm{~mL}$ of $0.5 \%$ thiobarbituric acid (TBA) in 20\% TCA solution was added into $1 \mathrm{~mL}$ of supernatant and incubated at $96^{\circ} \mathrm{C}$ for $30 \mathrm{~min}$. The tubes were cooled by transferring into an ice bath. The absorbance of the supernatant was recorded at $532 \mathrm{~nm}$. Standard curve was generated from MDA standard. The concentration of MDA in samples was calculated from absorbance calibration curve.

\section{Peroxidase (POX) activity}

Peroxidase activity of leaves was assayed by the method followed by Sanchez et al. [31]. The activity of peroxidase was expressed as:

Specific activity $\left(\mathrm{UA} \mathrm{mg} \mathrm{m}^{-1}\right.$ protein $)=$ Unit activity $\left(\mathrm{U} \mathrm{min}^{-1} \mathrm{~g}^{-1} \mathrm{FM}\right) /$ Protein content ( $\left.\mathrm{mg} \mathrm{g}^{-1} \mathrm{FM}\right)$. 


\section{Quantification of total Se, $\mathrm{Mg}$ and $P$}

Element analysis was carried out by inductively coupled plasma optical emission spectroscopy (ICP-OES) (Perkin Elmer OPTIMA 3300 DV) and inductively coupled plasma mass spectrometry (ICP-MS) (Thermo Elemental X7). Dried samples $(1 \pm 0.01 \mathrm{~g})$ were homogenized and decomposed by $\mathrm{HNO}_{3}-\mathrm{H}_{2} \mathrm{O}_{2}$ treatment as previously described [16]. Briefly, samples were kept in $10 \mathrm{~mL}$ concentrated $\mathrm{HNO}_{3}$ overnight, then heated to $60{ }^{\circ} \mathrm{C}$ for $45 \mathrm{~min}$ in a LABOR MIM OE 718/A block digestion apparatus. Following the first digestion step, $3 \mathrm{~mL} 30 \% \mathrm{H}_{2} \mathrm{O}_{2}$ was added to the samples and digestion was continued at $120{ }^{\circ} \mathrm{C}$ for another $90 \mathrm{~min}$. After cooling the samples to room temperature, volume was adjusted to $50 \mathrm{~mL}$ with deionized water. Samples were then mixed by shaking and filtered through FILTRAK 388 filters.

\section{Data analysis}

Data were statistically analyzed using SPSS, 19.0 software (2010). Standard error was calculated and analysis of variance (ANOVA) was performed on the data to determine the least significance difference (Tukey test) between treatment means with the level of significance at $\mathrm{P} \leq 0.05$.

\section{RESULTS}

\section{Photosynthetic parameters}

Although chlorophyll content is sensitive to environmental changes, no significant difference in relative chlorophyll content was shown in green pea leaves treated with $\mathrm{Se}^{\mathrm{IV}}$ in $1-30 \mathrm{mg} \mathrm{kg}^{-1}$ concentration range (Fig. 1A). In contrast, $90 \mathrm{mg} \mathrm{kg}^{-1} \mathrm{Se}^{\mathrm{IV}}$ significantly decreased the relative chlorophyll content by $34.7 \%$ in comparison to control.

The maximal photochemical efficiency of PSII $(\mathrm{Fv} / \mathrm{Fm})$ is derived parameter of chlorophyll $a$ fluorescence transient, point out to maximal quantum yield of PSII did not change significantly in case of $\mathrm{Se}^{\mathrm{IV}} 0-90 \mathrm{mg} \mathrm{kg}^{-1}$ and Se $\mathrm{SI}^{\mathrm{VI}} 1 \mathrm{mg} \mathrm{kg}^{-1}$ concentration range, respectively (Fig. 1B). On the other hand, $3 \mathrm{mg} \mathrm{kg}^{-1} \mathrm{Se}^{\mathrm{IV}}$ increased the actual photochemical efficiency of PSII $\left(\Phi_{\mathrm{PSII}}\right)$ significantly, whereas; 30 and $90 \mathrm{mg}$ $\mathrm{kg}^{-1} \mathrm{Se}^{\mathrm{IV}}$ treatments decreased this value (Fig. 1C).

\section{Malondialdehyde content}

The concentration of MDA in the shoot tissues can indicate the level of oxidative damage caused by Se added to the soil. The accumulation of MDA in the green pea leaves was stimulated after the Se treatment, by $13 \%$ in the presence of $90 \mathrm{mg} \mathrm{kg}^{-1}$ 
$\mathrm{Se}^{\mathrm{IV}}$, as compared to the control plants (Fig. 1D). On the other hand, in plants supplied individually with $3 \mathrm{mg} \mathrm{kg}^{-1} \mathrm{Se}^{\mathrm{IV}}$, the MDA concentration significantly decreased by $18.4 \%$ in comparison to the control plants.

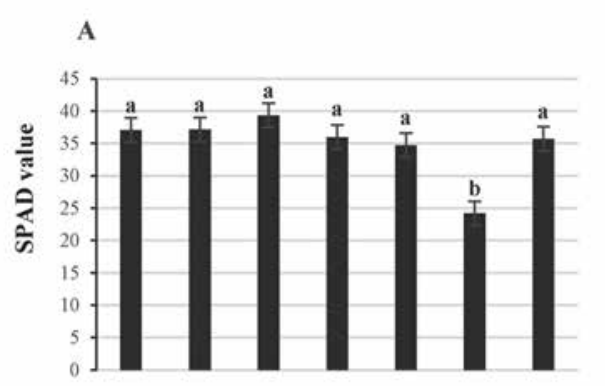

B
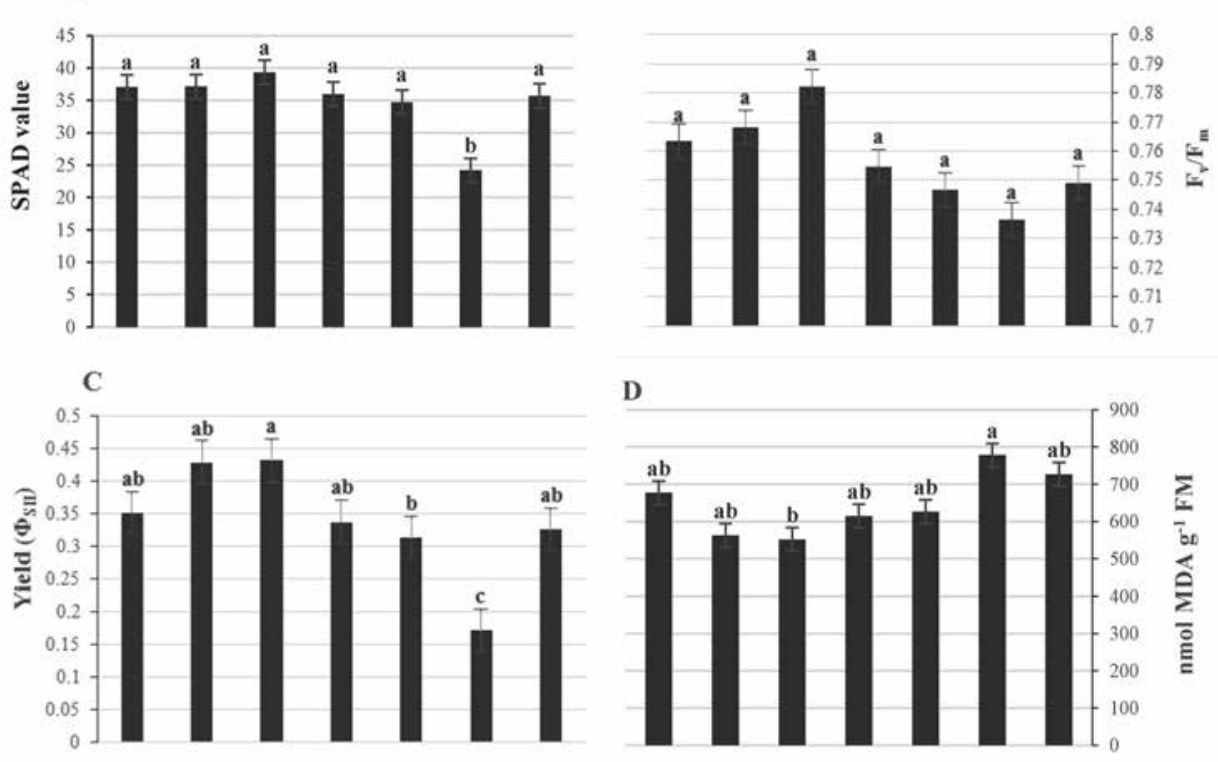

D

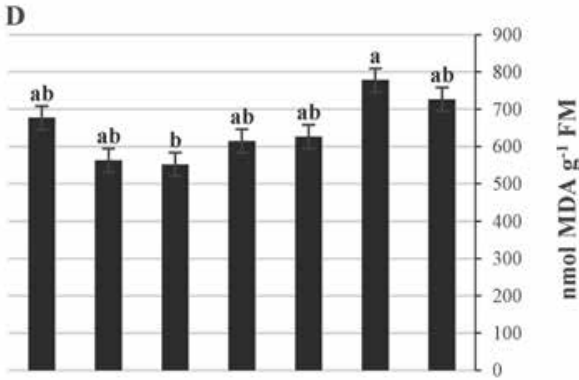

$\mathbf{E}$

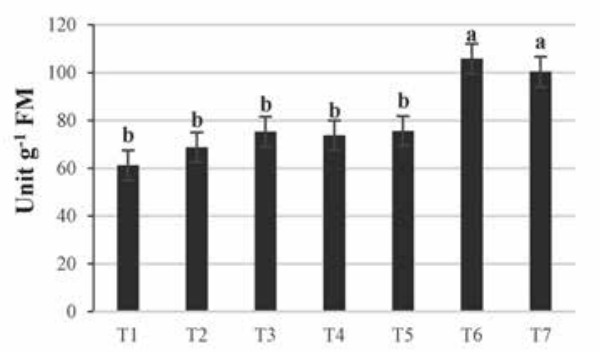

Fig. 1. Effect of different concentration of applied Se forms induced changes in (A) SPAD chlorophyll content, (B) maximal photochemical efficiency of PSII $\left(\mathrm{F}_{\mathrm{v}} / \mathrm{F}_{\mathrm{m}}\right)(\mathbf{C})$ actual photochemical efficiency of PSII $\left(\Phi_{\text {PSII }}\right)$, (D) concentration of MDA in leaves $(\mathbf{E})$ activity of peroxidase in leaves at 50 days stage of growth. T1 = control; $\mathrm{T} 2=\mathrm{Se}^{\mathrm{IV}}\left(1 \mathrm{mg} \mathrm{kg}^{-1}\right) ; \mathrm{T} 3=\mathrm{Se}^{\mathrm{IV}}\left(3 \mathrm{mg} \mathrm{kg}^{-1}\right) ; \mathrm{T} 4=\mathrm{Se}^{\mathrm{IV}}\left(10 \mathrm{mg} \mathrm{kg}^{-1}\right) ; \mathrm{T}^{2}=\mathrm{Se}^{\mathrm{IV}}$ $\left(30 \mathrm{mg} \mathrm{kg}^{-1}\right) ; \mathrm{T} 6=\mathrm{Se}^{\mathrm{IV}}\left(90 \mathrm{mg} \mathrm{kg}^{-1}\right) ; \mathrm{T} 7=\mathrm{Se}^{\mathrm{VI}}\left(1 \mathrm{mg} \mathrm{kg}^{-1}\right)$. Significant differences in the mean value of each treatment group are indicated by different lower case letter based on Tukey test $(p<0.05, n=5 \pm$ s.e. $)$ and the same lower case letters shows no significant difference between the treatments 


\section{Peroxidase (POX) activity}

The treatment of plants with various concentration of $\mathrm{Se}^{\mathrm{IV}}\left(1,3,10,30,90 \mathrm{mg} \mathrm{kg}^{-1}\right)$ and $1 \mathrm{mg} \mathrm{kg}^{-1} \mathrm{Se}^{\mathrm{VI}}$ increased the POX activity of leaves by $10.9 \%, 18.6 \%, 16.9 \%$, $18.8 \% 42.1 \%$ and $39 \%$ over the control (Fig. 1E).

\section{Quantification of total Se}

The total Se content in all of the green pea organs increased when enhancing both $\mathrm{Se}^{\mathrm{IV}}$ and $\mathrm{Se}^{\mathrm{VI}}$ concentrations in the soil (Table 2). The relationship between the total Se content and the $\mathrm{Se}^{\mathrm{VI}}$ dose $\left(0\right.$ and $\left.1 \mathrm{mg} \mathrm{kg}^{-1}\right)$ was linear, and in the $1 \mathrm{mg} \mathrm{kg}^{-1} \mathrm{Se}^{\mathrm{VI}}$ exposed green pea the total Se content in roots was 1.3-, 6.8- and 5.7-fold higher than in shoots, pods and seeds, respectively. A 30 and $90 \mathrm{mg} \mathrm{kg}^{-1} \mathrm{Se}^{\mathrm{IV}}$ treated samples displayed significant differences at lower concentrations of $\mathrm{Se}^{\mathrm{IV}}$ in all of the organs and roots, seeds, shoots and pods had the order of the most to the least total Se content.

Total Se contents of green pea plants in different parts of roots, shoots, pods, and seeds showed an significant increase after biofortification, with respect to the initial concentrations of Se in plants not supplemented with Se (controls); without supplementation only traces of Se could be detected (Table 2).

Table 2

The accumulation of Se in the green pea plant's organs $\left(\mathrm{mg} \mathrm{kg}^{-1} \mathrm{DM}\right)$ cultivated with different concentration of applied Se forms (selenite: $\mathrm{Se}^{\mathrm{IV}}$ and selenate: $\mathrm{Se}^{\mathrm{VI}}$ ) for a growing period of 50 days

\begin{tabular}{|c|c|c|c|c|}
\hline $\begin{array}{c}\text { Applied Se } \\
\left(\mathrm{mg} \mathrm{kg}^{-1}\right)\end{array}$ & Root & Shoot & Pod & Seed \\
\hline Control & $0.84 \pm 0.23^{\mathrm{c}}$ & $0.32 \pm 0.03^{\mathrm{d}}$ & $0.19 \pm 0.01^{\mathrm{d}}$ & $0.25 \pm 0.1^{\mathrm{c}}$ \\
\hline $1 \mathrm{Se}^{\mathrm{IV}}$ & $3.87 \pm 0.00^{\mathrm{c}}$ & $0.36 \pm 0.01^{\mathrm{d}}$ & $0.23 \pm 0.02^{\mathrm{d}}$ & $0.26 \pm 0.3^{\mathrm{c}}$ \\
\hline $3 \mathrm{Se}^{\mathrm{IV}}$ & $49.35 \pm 4.88^{\mathrm{c}}$ & $3.83 \pm 0.35^{\mathrm{d}}$ & $2.80 \pm 0.10^{\mathrm{d}}$ & $7.39 \pm 1.13^{\mathrm{c}}$ \\
\hline $10 \mathrm{Se}^{\mathrm{IV}}$ & $147 \pm 64^{\mathrm{c}}$ & $10.02 \pm 0.36^{\mathrm{c}}$ & $7.85 \pm 0.22^{\mathrm{c}}$ & $16.5 \pm 0.62^{\mathrm{c}}$ \\
\hline $30 \mathrm{Se}^{\mathrm{IV}}$ & $541 \pm 81^{\mathrm{b}}$ & $20.97 \pm 0.93^{\mathrm{b}}$ & $18.90 \pm 0.56^{\mathrm{b}}$ & $41.5 \pm 5.17^{\mathrm{b}}$ \\
\hline $90 \mathrm{Se}^{\mathrm{IV}}$ & $1401 \pm 64^{\mathrm{a}}$ & $56.37 \pm 4.61^{\mathrm{a}}$ & $54.07 \pm 3.52^{\mathrm{a}}$ & $343 \pm 16^{\mathrm{a}}$ \\
\hline $\begin{array}{c}\text { Applied Se} \\
\left(\mathrm{mg} \mathrm{kg}{ }^{-1}\right.\end{array}$ & Root & Shoot & Pod & Seed \\
\hline Control & $0.84 \pm 0.23$ & $0.32 \pm 0.03$ & $0.19 \pm 0.01$ & $0.25 \pm 0.1$ \\
\hline $1 \mathrm{Se}^{\mathrm{IV}}$ & $1220 \pm 0$ & $886 \pm 6.08$ & $178 \pm 4$ & $214 \pm 16$ \\
\hline
\end{tabular}

Significant differences in the mean value of each treatment group are indicated by different lower case letter based on Tukey test $(p<0.05, n=3 \pm$ s.e. $)$. 


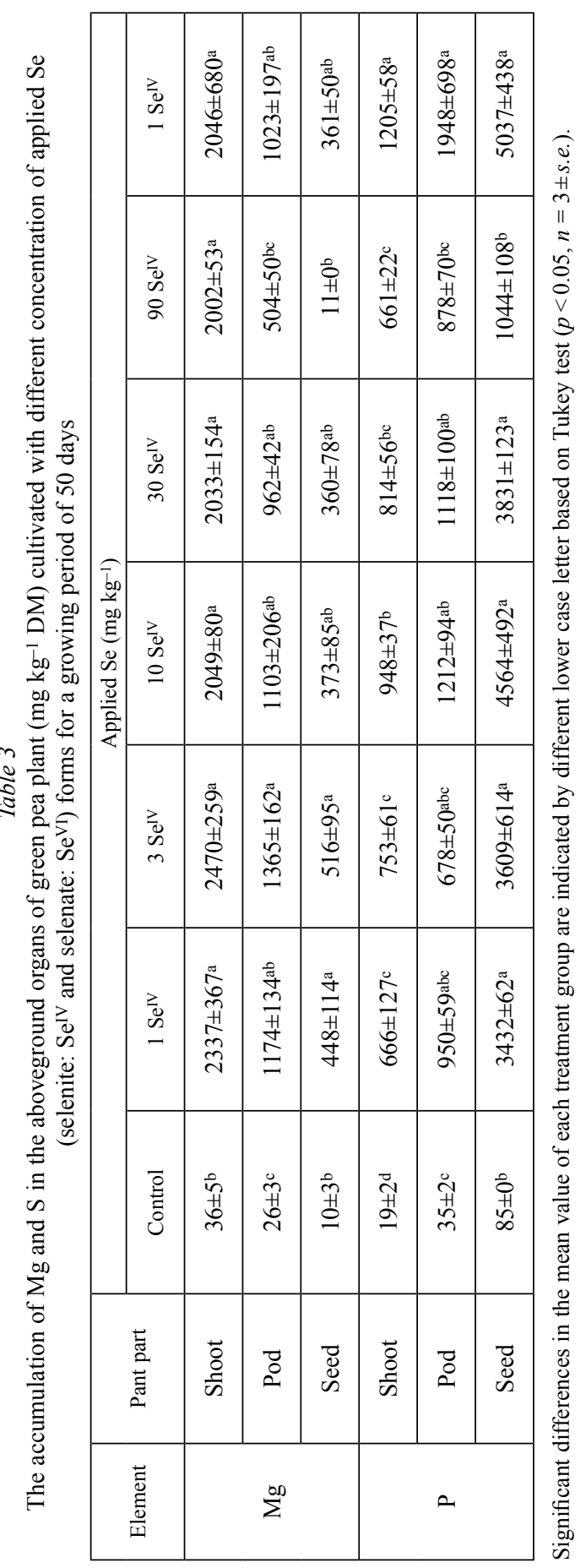




\section{Quantification of total $\mathrm{Mg}$ and P in the aboveground organs}

The total $\mathrm{Mg}$ content in the $3 \mathrm{mg} \mathrm{kg}^{-1}$ of $\mathrm{Se}^{\mathrm{IV}}$ treated green pea was the highest and $98 \%$ increase was observed in all of the aboveground organs, in comparison to the controls (Table 3). Moreover, in all concentrations, the order according to the highest amounts was shoot, pod and seed. Whereas the total $\mathrm{P}$ content in the $1 \mathrm{mg} \mathrm{kg}^{-1}$ of SeVI was the highest in all of the organs and by $98 \%$ increase was seen comparing with the controls. In contrast, total amount of $\mathrm{P}$ accumulated in the highest degree, into the seed, followed by pod and shoot, respectively.

Treatments with $90 \mathrm{mg} \mathrm{kg}^{-1}$ of $\mathrm{Se}^{\mathrm{IV}}$ caused a significant decrease in both $\mathrm{Mg}$ and $\mathrm{S}$ levels in different parts of the plant. In addition, the total $\mathrm{Mg}$ and $\mathrm{S}$ contents in different parts of green pea situated above the ground such as shoots, pods, and seeds showed a significant increase after biofortification, with respect to the initial concentrations of them in plants not supplemented with Se (controls) (Table 3).

\section{DISCUSSIONS}

There is increasing evidence that Se can have beneficial effects on the growth, yield formation and stress tolerance of plants [11]. The physiological, biochemical or molecular mechanisms behind the stimulated growth and improved tolerance have not yet been determined completely. Nevertheless, enhanced antioxidant capacity (reviewed in 11) and more efficient accumulation of carbohydrates [37] are thought to be contributing factors in the better performance of the plants.

The response of green pea plants to Se exposure has been previously described by only a few authors $[29,35]$, hence the literature in this field is quite limited.

It is believed that improved growth is the result of efficient chlorophyll florescence parameters and enhanced chlorophyll synthesis. The findings of the present study revealed that effective quantum yield of PSII photochemistry $\left(\Phi_{\text {PSII }}\right)$ increased significantly in the presence of $\operatorname{Se} \mathrm{IV}^{\mathrm{N}}\left(3 \mathrm{mg} \mathrm{kg}^{-1}\right)$ whereas, increasing the concentration of Se lowered this parameter and also chlorophyll content. Our findings are in line with work that corroborated low doses of Se enhanced photosynthesis in rice seedlings [41]. However, Se toxicity induces the damage of photosynthetic apparatus, inhibits photosynthesis, and results in the over-production of starch [41].

MDA formation in plants exposed to adverse environmental conditions is a consequence of lipid peroxidation caused by oxidative stress [17]. In green pea plants supplied with $3 \mathrm{mg} \mathrm{kg}^{-1} \mathrm{Se}^{\mathrm{IV}}$, MDA concentrations in the leaf tissues decreased significantly, as compared to the control plants. In the plants supplied with the higher dose of $\mathrm{Se}^{\mathrm{IV}}\left(90 \mathrm{mg} \mathrm{kg}^{-1}\right)$, the level of MDA was the highest. Consistent with our results, several studies have also shown that Se supplementation may counteract the accumulation of harmful lipid peroxides in the plant cells $[28,30,46]$. These results can be attributed to the anti-oxidative effects of Se on plants reported previously $[11,12,28]$. 
POX is a type of antioxidant enzymes that is triggered in plants to balance the excess of reactive oxygen species (ROS) [4]. This antioxidant can react with ROS directly or indirectly via enzyme catalysis to counteract the production of ROS, under stress conditions, as Mittler [24] believed that ROS, under control conditions, act as signals for the activation of the stress response and defence pathways. In the present investigation, under excess of Se, enzymatic POX antioxidant system increased to scavenge the Se induced excess ROS. It has been shown that excess Se gives rise to the robust accumulation of ROS in plants, although the actual role of Se in plants has not yet been resolved [25]. Feng et al. [8] proposed that the increased production of ROS at high Se levels may be partially related to an imbalance in the levels of glutathione (GSH), thiols (SH), ferredoxins (Fdred) and/or NADPH, which can play vital roles in the assimilation of Se. If these substances are not sufficient to simultaneously meet the needs of Se-assimilation and ROS quenching, the addition of Se may lead to a ROS burst and the inhibition of plant growth. However, in the present study, treatment of plants with $90 \mathrm{mg} \mathrm{kg}^{-1} \mathrm{Se}^{\mathrm{IV}}$ enhanced the participation of antioxidant $\mathrm{POX}$ at protective mechanisms.

Different parts of green pea plants exposed to (treated with) $\mathrm{Se}^{\mathrm{VI}}$ presented higher concentrations of total Se, as a likely consequence of selenite using the sulphate path through plants [51], other than its generally higher uptake/retention and translocation efficiencies $[13,15]$. Also, Se levels in the root tissues were much higher than in the aboveground parts in case of all $\mathrm{Se}^{\mathrm{IV}}$ concentrations applied and in case of $1 \mathrm{mg} \mathrm{kg}^{-1}$ $\mathrm{Se}^{\mathrm{VI}}$ as well.

Based on this study we can conclude that $3 \mathrm{mg} \mathrm{kg}^{-1}$ of Se $\mathrm{Se}^{\mathrm{IV}}$ increases the accumulation of $\mathrm{Mg}$ in green pea plants and especially in its shoots but high concentration of $\mathrm{Se}^{\mathrm{IV}}\left(\geq 30 \mathrm{mg} \mathrm{kg}^{-1}\right)$ inhibits this process. A number of literature data $[6,21,43,47$, 48] confirm these findings. Also, $1 \mathrm{mg} \mathrm{kg}^{-1}$ of $\mathrm{Se}^{\mathrm{VI}}$ caused the highest accumulation of $\mathrm{P}$ in all the aboveground parts of green pea plants and particulares in the seeds. On the other hand, excessive uptake of Se $\left(90 \mathrm{mg} \mathrm{kg}^{-1} \mathrm{Se}^{\mathrm{IV}}\right)$ by the plant made a reverse condition. Earlier results of Sing [34] and Liu and Gu [19] are in agrement with our findings, too.

\section{ACKNOWLEDGEMENTS}

We would like to thank associate professor Dr. Andrea Balláné Kovács, Ph.D. (University of Debrecen, Hungary) for her help to set up these experiments and to Áron Soós, Ph.D. student (University of Debrecen, Hungary) for quantification of total $\mathrm{Se}, \mathrm{Mg}$ and $\mathrm{P}$.

\section{REFERENCES}

1. Abel, S. C., Ticconi, A. C., Delatorre, A. (2002) Phosphate sensing in higher plants. Physiol. Plant $115,1-8$.

2. Acikgoz, E., Katkat. V., Omeroglu, S., Okan, B. (1985) Mineral elements and amino acid concentrations in field pea and common vetch herbages and seeds. J. Agron. Crop Sci. 55, 179-185 
3. Alfthan, G., Eurola, M., Ekholm, P., Venäläien, E. R., Root, T., Korkalainen, K., Hartikainen, H., Salminen, P., Hietaniemi, V., Aspila, P., Aro, A. (2015) Effect on nationwide addition of selenium to fertilizers on foods, and animals and human health: from deficiency to optimal selenium status of the population. J. Trace Elem. Med. Biol. 31, 142-147.

4. Asada, K. (2006) Production and scavenging of reactive oxygen species in chloroplast and their functions. Plant Physiol. 14, 391-396.

5. Banuelos, G. S., Arroyo, I., Pickering, I. J., Yang, S. I., Freeman, J. L. (2015) Selenium biofortification of broccoli and carrots grown in soil amended with Se-enriched hyperaccumulator. Stanleya Pinnata. Food Chem. 166, 603-608.

6. De Souza, M. P., Pilon-Smits, E. A. H., Mel Lytle, C., Hwang, S., Tai, J., Honma, T. S. U., Yeh, L., Terry, N. (1998) Rate-limiting steps in selenium assimilation and volatilization by Indian mustard. Plant Physiol. 117, 1487-1494.

7. Dworkin, B. M. (1994) Selenium deficiency in HIV infection and the acquired immunodeficiency syndrome (AIDS). Chem. Biol. Interact 91, 181-186.

8. Feng, R., Wei, C., Tu, S. (2013) The roles of selenium in protecting plants against abiotic stresses. Environ. Exp. Bot. 87, 58-68.

9. Germ, M., Pongrac, P., Regvar, M., Vogel-Mikus, K., Stibilj, V., Jacimovic, R., Kreft, I. (2013) Impact of double $\mathrm{Zn}$ and Se biofortification of wheat plants on the element concentrations in the grain. Plant Soil Environ. 59, 316-321.

10. Graham, R. D., Welch, R. M., Saunders, D. A., Ortiz-Monasterio, I., Bouis, H. E., Bonierbale. M., de Haan, S., Burgos, G., Thiele, G., Liria, R. (2007) Nutritious subsistence food systems. Adv. Agron. 92, 1-74.

11. Hartikainen, H. (2005) Biogeochemistry of selenium and its impact on food chain quality and human health. J. Trace Elem. Med. Bio. 18, 309-318.

12. Hawrylak-Nowak, B. (2009) Beneficial effects of exogenous selenium in cucumber seedlings subjected to salt stress. Biol. Trace Elem. Res. 132, 259-269.

13. Hopper, J. L., Parker, D. R. (1999) Plant availability of selenite and selenate as influenced by the competing ions phosphate and sulfate. Plant Soil 210, 199-207.

14. Iqbal, M., Hussain, I., Liaqat, H., Arslan, Ashraf, M., Rasheed, R. (2015) Exogenously applied selenium reduces oxidative stress and induces heat tolerance in spring wheat. Plant Physiol. Biochem. 94, 95-103.

15. Keskinen, R., Yli-Halla, M., Hartikainen, H. (2013) Retention and uptake by plants of added selenium in peat soils. Commun. Soil Sci. Plant Anal. 44, 3465-3482.

16. Kovács, B., Győri, Z., Prokisch, J., Loch, J., Dániel, P. (1996) A study of plant sample preparation and inductively coupled plasma emission spectrometry parameters. Commun. Soil Sci. Plant Anal. 27, $1177-1198$

17. Lee, S. H., Ahsan, N., Lee, K. W., Kim, D. H., Lee, D. G., Kwak, S. S., Kwon, S. Y., Kim, T. H., Lee, B. H. (2007) Simultaneous overexpression of both CuZn superoxide dismutase and ascorbate peroxidase in transgenic tall fescue plants confers increased tolerance to a wide range of abiotic stresses. J. Plant Physiol. 164, 1626-1638.

18. Li, H. F., McGrath, S. P., Zhao, F. J. (2008) Selenium uptake, translocation and speciation in wheat supplied with selenate or selenite. New Phytol. 178, 92-102.

19. Liu, K., Gu, Z. (2009) Selenium accumulation in different brown rice cultivars and its distribution infractions. J. Agric. Food Chem. 57, 695-700.

20. Liu, K., Zhao, K., Duan, B., Hu, C., Zhao, X., Guo, Z. (2015) Effect of applied sulphur on the uptake by wheat of selenium applied as selenite. Plant Soil 386, 35-45.

21. Longchamp, M., Angeli, N., Castrec-Rouelle, M. (2013) Selenium uptake in Zea mays supplied with selenate or selenite under hydroponic conditions. Plant Soil 362, 107-117.

22. Marschner, H. (1995) Mineral Nutrition of Higher Plants. Academic Press, London.

23. Mayer, J. E., Pfeiffer, W. H., Beyer, P. (2008) Biofortified crops to alleviate micronutrient malnutrition. Curr. Opin. Plant Biol. 11, 166-170. 
24. Mittler, R. (2002) Oxidative stress, antioxidants and stress tolerance. Trends Plant Sci. 7, 405-410.

25. Mroczek-Zdyrska, M., Wójcik, M. (2011) The influence of selenium on root growth and oxidative stress induced by lead in Vicia faba L. minor plants. Biol. Trace Elem. Res. 147, 320-328.

26. Nagy, K., Lévai, L., Kovács, B. (2010) The effect of selenium supply on maize and sunflower. Növénytermelés 59, 61-84.

27. Nestel, P., Bouis, H. E., Meenakshi, J. V., Pfeiffer, W. (2006) Biofortification of staple food crops. J. Nutr. 136, 1064-1067.

28. Pedrero, Z., Madrid, Y., Hartikainen, H., Cámara, C. (2008) Protective effect of selenium in broccoli (Brassica oleracea) plants subjected to cadmium exposure. J. Agric. Food Chem. 56, 266-271.

29. Poblaciones, M. J., Sara, M., Rodrigo Oscar Santamaría (2012) Evaluation of the potential of peas (Pisum sativum L.) to be used in selenium biofortification programs under mediterranean conditions. Biol. Trace Elem. Res. 151, 132-137.

30. Saidi, I., Chtourou, Y., Djebali, W. (2014) Selenium alleviates cadmium toxicity by preventing oxidative stress in sunflower (Helianthus annuus) seedlings. Plant Physiol. 171, 85-91.

31. Sanchez, M., Revilla, G., Zarra, I. (1995) Changes in peroxidase activity associated with cell walls during pine hypocotyl growth. Ann. Bot. 75, 415-419.

32. Schachtman, D. P., Reid, R. J., Ayling, S. M. (1998) Phosphorus uptake by plants: from soil to cell. Plant Physiol. 16, 447-453.

33. Schreiber, U., Schliwa, U., Bilger, W. (1986) Continuous recording of photochemical and non-photochemical chlorophyll fluorescence quenching with a new type of modulation fluorometer. Photosynth. Res. 10, 51-62.

34. Singh, B. R. (1991) Selenium content of wheat as affected by selenate and selenite contained in a Cl- or $\mathrm{SO}_{4}$-based NPK fertilizer. Fertili. Res. 30, 1-7.

35. Smrkolj, P., Germ, M., Kreft, I., Stibilj, V. (2006) Respiratory potential and Se compounds in pea (Pisum sativum L.) plants grown from Se-enriched seeds. J. Exp. Bot. 57(14), 3595-3600.

36. Thavarajah, D., Warkentin, T., Vandenberg, A. (2010) Natural enrichment of selenium in Saskatchewan field peas (Pisum sativum L.). Can. J. Plant Sci. 90, 383-389.

37. Turakainen, M., Hartikainen, H., Seppänen, M. (2004) Effects of selenium treatments on potato (Solanum tuberosum L.) growth and concentrations of soluble sugars and starch. J. Agric. Food Chem. 52, 5378-5382.

38. Vance, C. P. (2001) Symbiotic nitrogen fixation and phosphorus acquisition. Plant nutrition in a world of declining renewable resources. Plant Physiol. 127, 390-397.

39. Vance, C. P., Uhde-Stone, C. D., Allan, L. (2003) Phosphorus acquisition and use: critical adaptations by plants for securing a nonrenewable resource. New Phytol. 157, 423-447.

40. Wang, J., Wang, Z., Mao, H., Zhao, H., Huang, D. (2013) Increasing Se concentration in maize grain with soil-or-foliar-applied selenite on the Loess plateau in China. Field Crops Res. 150, 83-90.

41. Wang, Y. D., Wang, X., Wong, Y. S. (2012) Proteomics analysis reveals multiple regulatory mechanisms in response to selenium in rice. J. Proteomics 75, 1849-1866.

42. White, P. J., Broadley, M. R. (2005) Biofortifying crops with essential mineral elements. Trends Plant Sci. 10, 586-593.

43. Ximenez-Embun, P., Alonso, I., Madrid-Albarran, Y., Camara, C. (2004) Establishment of selenium uptake and species distribution in lupine, India mustard and sunflower plants. J. Agric. Food Chem. 52, 832-838.

44. Yuan, H., Liu, D. (2008) Signaling components involved in plant responses to phosphate starvation J. Integr. Plant Biol. 50, 849-859.

45. Zayed, A., Lytle, C. M., Terry, N. (1998) Accumulation and volatilization of different chemical species of selenium by plants. Planta 206, 284-292.

46. Zembala, M., Filek, M., Walas, S., Mrowiec, H., Kornás, A., Miszalski, Z., Hartikainen, H. (2010) Effect of selenium on macro- and microelement distribution and physiological parameters of rape and wheat seedlings exposed to cadmium stress. Plant Soil 329, 457-468. 
47. Zhang, L., Shi, W., Wang, X. (2006) Difference in selenite absorption between high and low-selenium rice cultivars and its mechanism. Plant Soil 282, 183-193.

48. Zhang, Y., Pan, G., Chen, J., Hu, Q. (2003) Uptake and transport of selenite and selenate by soybean seedlings of two genotypes. Plant Soil 253, 437-443.

49. Zhang, Z., Huang, R. (2013) Analysis of malondialdehyde, chlorophyll proline, soluble sugar, and glutathione content in Arabidopsis seedling. 3(14), e817. DOI: 10.21769/BioProtoc.817; Full text.

50. Zhao, F. J., McGrath, S. P. (2009) Biofortification and phytoremediation. Current Opinion in Plant Biology 12, 373-380.

51. Zhu, Y.-G., Pilon-Smits, E. A. H., Zhao, F.-J., Williams, P. N., Meharg, A. A. (2009) Selenium in higher plants: understanding mechanisms for biofortification and phytoremediation. Trends Plant Sci. $14,436-442$. 